\title{
Analisis Penggunaan Media Puppet Show untuk Peningkatan Kemampuan Menyimak dan Bercerita Siswa
}

\author{
Zulfikar Nurhanani ${ }^{1}$, Bambang Budi Wiyono ${ }^{2}$, Nurchasanah $^{3}$ \\ ${ }^{1}$ Pendidikan Dasar-Universitas Negeri Malang \\ ${ }^{2}$ Manajemen Pendidikan-Universitas Negeri Malang \\ ${ }^{3}$ Pendidikan Bahasa dan Sastra Indonesia-Universitas Negeri Malang
}

\begin{tabular}{l} 
INFO ARTIKEL \\
\hline Riwayat Artikel: \\
Diterima: 10-12-2019 \\
Disetujui: 21-07-2020 \\
Kata kunci: \\
listening ability; \\
storytelling skills; \\
puppet show; \\
kemampuan menyimak; \\
kemampuan bercerita; \\
puppet show
\end{tabular}

Alamat Korespondensi:

Zulfikar Nurhanani

Pendidikan Dasar

Universitas Negeri Malang

Jalan Semarang 5 Malang

e-mail: hanizulfikar25@gmail.com

\begin{abstract}
ABSTRAK
Abstract: Supporting students can develop well supporting the selection of appropriate media specifically in developing listening and storytelling abilities. Researchers looking for the influence of the shadow play media show the ability to listen and tell stories in grade II elementary school. This study uses quantitative research with the design of Quasi-Experiment Pretest and posttest Control Group Design. Displaying performance shows using the Puppet Show media has been in accordance with the steps of the activities that are developed, and there is a development with the use of the Puppet Performance media to the ability to listen and tell the second grade students with sig. the experimental class of 0.144 which is smaller than 0.05 in the control class.

Abstrak: Kemampuan berbahasa siswa dapat berkembang dengan baik apabila didukung pemilihan media yang tepat khususnya dalam pengembangan kemampuan menyimak dan bercerita. Peneliti mencari pengaruh media puppet show terhadap kemampuan menyimak dan bercerita kelas II SD. Penelitian ini menggunakan pendekatan penelitian kuantitatif dengan rancangan Quasi-Experiment Pretest and postest Control Group Design. Hasilnya menunjukkan pelaksanaan pembelajaran dengan menggunakan media Puppet Show telah sesuai dengan langkah kegiatan yang dikembangkan, dan ada pengaruh dengan penggunaan media Puppet Show terhadap kemampuan menyimak dan bercerita siswa kelas II dengan nilai sig. kelas eksperimen yaitu 0,144 yang lebih kecil dari 0,05 pada kelas kontrol.
\end{abstract}

Bahasa Indonesia di Sekolah Dasar ialah disiplin ilmu yang sebaiknya memakai metode variatif dalam setiap pelaksanaannya. Pada aspek keterampilan berbahasa, kemampuan menyimak seyogyanya memperoleh bagian lebih banyak dalam pembelajaran bahasa Indonesia (Syafrina, Dermawan, Widiati, 2017). Kompetensi Bahasa Indonesia di Sekolah Dasar mencakup empat keterampilan berbahasa. Menurut (Tarigan, 2008) dan Kementerian Pendidikan dan Kebudayaan (2003) kemampuan berbahasa dalam kurikulum di sekolah, meliputi empat segi kemampuan, yakni kemampuan menyimak, berbicara, membaca, dan menulis. (Akhadiah, 1992) menyatakan keempat kemampuan itu haruslah dikuasai oleh siswa agar mampu bersaing karena dalam keempat kemampuan dasar tersebut sangatlah urgen dalam kegiatan belajar mengajar.

Salah satu dari keempat kemampuan berbahasa yang di Sekolah Dasar yaitu kemampuan menyimak. Menurut (Saddhono, 2012) kemampuan menyimak proses paling awal dimana seseorang bisa mengucapkan bahasa, secara berturut-turut prosesnya diawali dengan menyimak, berbicara, membaca, dan diakhiri menulis. Selaras Mudiono (2009); Anderson dalam Tarigan (2008) menyatakan menyimak rangkaian aktivitas mendengar, mengenali, dan memaknai suara bahasa lalu mengevaluasi dan memberikan umpan balik pesan yang terkandung lewat bahasa tersebut. Menurut (Rosdawita, 2013) menyimak ialah rangkaian yang mencankup aktivitas mendengarkan bunyi bahasa, mengidentifiaksi, menginterpretasikan, menilai, dan menanggapi makan yang dimaksud dan menurut (Ariani, Dawud, \& Basuki, 2019) menyimak melibatkan aktivitas mental. Sementara itu, untuk bercerita (Mulyati, 2009) menyatakan bercerita ialah salah satu keterampilan berbahasa yang produktif artinya lewat bercerita kita dapat memunculkan gagasan dan ide pikiran. Bercerita di dalam kelas merupakan salah satu cara untuk mengatasi kurangnya minat baca dengan meningkatkan bahasa lisan, pemahaman dalam membaca, dan menulis (Pennycuff, 2008). Menurut (Fatimah, 2015) Keterampilan berbicara ialah keterampilan produktif bahasa pertama yang mampu dikuasai seseorang. Manfaat bercerita menurut (Alterio, 2003) adalah proses bercerita membantu mereka untuk memahami peristiwa latihan dan memungkinkan lapisan makna agar terungkap. 
Pembelajaran yang efektif ialah kegiatan yang menciptakan kebermanfaatan pada siswa lewat pemakaian langkahlangkah yang tepat. Chrisyarani (2018) mengemukakan bahwa guna memunculkan minat belajar siswa, guru diharuskan dapat mengaplikasikan cara belajar yang menyenangkan. Pembelajaran yang menarik juga bisa ditunjang dengan penerapan media yang dapat menarik minat siswa. Untuk itu dalam upaya menciptakan pembelajara yang menarik, guru harus dapat menentukan media pembelajaran yang sesuai guna mencapai keefektifan KBM. Media ialah orang, benda, ataupun kejadian yang menciptakan suasana yang bisa membuat siswa mendapatkan aspek pengetahuan, keterampilan, dan sikap (Arsyad, 2013). Saat pembelajaran, guru seharusnya memfasilitasi siswa dengan menggunakan dan mengembangkan media pembelajaran sehingga pembelajaran dapat berlangsung efektif (Permatasari, Sudarmiatin, \& Mudiono, 2019). Hal ini sejalan dengan pendapat dari (Prananta, Yunina Resmi; Setyosari, Punandji; Santoso, 2017) guru seharusnya memakai dan mengembangkan media pembelajaran yang bisa memunculkan motivasi belajar siswa sehingga pembelajaran berlangsung efektif. Kemudian Gagne dalam (Sadiman, Arief, Rahardjo, Haryono, 2010) memaparkan bahwa media ialah bermacam-macam aspek dalam lingkungan anak yang dapat memunculkan rasa ketertarikan belajar. (Ibrahim, 2006) membagi media pembelajaran menjadi visual, audio, audio-visual, multimedia, dan realita.

Salah satu media yang dapat dipakai dalam memengaruhi pikiran, perasaan, perhatian, dan sikap siswa yaitu media Hand Puppet atau Puppet Show. Penetapan media boneka tangan diselaraskan dengan kepribadian siswa, bahan pembelajaran, dan tujuan yang ditentukan (Chrisyarani, 2018). Menurut (Bachri, 2005) boneka ialah replika dari wujud manusia dan hewan berbentuk dari sekian objek yang disenangi anak boneka ialah replika dari wujud manusia dan hewan. Menurut (Sukidi, 2015) boneka tangan dapat menjadi media untuk membantu siswa berani berekspresi atau mengungkapkan perasaan dan gagasannya. Media Puppet Show merupakan media audio visual. Dalam penggunaannya media puppet show menunjukkan keeefektifannya dalam pembelajaran. Oleh sebab itu, penyampaian materi lewat boneka dapat menarik perhatian siswa, siswapun ikut berpartisipasi dalam permainan boneka dengan cara memainkannya yang nantinya dapat meningkatkan imajinasi anak.

Penelitian ini didukung dan diperkuat oleh hasil temuan penulis melalui kegiatan observasi di SDN Wonomulyo 01 Kota Malang yang dilaksanakan pada hari selasa, 13 Mei 2019. Berdasarkan kegiatan observasi tersebut, penulis menemukan beberapa masalah pada pembelajaran bahasa Indonesia, khususnya pada kemampuan menyimak dan bercerita siswa kelas II Sekolah Dasar. Masih banyaknya siswa yang kurang fokus dan mendengarkan ketika rekannya membaca, siswa juga tidak memperhatikan pada saat guru menjelaskan dan menyampaikan materi hingga kurangnya penggunaan media ketika dilakukan kegiatan yang melibatkan kemampuan bercerita siswa. Hal tersebut membuat penulis tertarik untuk mengambil judul tesis "Pengaruh Media Puppet Show terhadap Kemampuan Menyimak dan Bercerita Siswa Kelas II Sekolah Dasar".

\section{METODE}

Pendekatan penelitian yang dipakai ialah kuantitatif dengan rancangan penelitian Quasi-Experiment. Desain QuasiExperiment yang dipakai dalam penelitian ini ialah Pretest and postest Control Group Design. Penelitian ini menggunakan dua kelas yaitu kelas kontrol dan kelas eksperimen, kelompok eksperimen ataupun kontrol mempunyai karakteristik sama.

\section{Instrumen Penelitian}

Penelitian dilakukan di SDN Wonomulyo 01 Malang Tahun Pelajaran 2018/2019. Akan ada dua subjek penelitian, yaitu 22 siswa kelas II A dan 23 siswa kelas II B dengan jumlah total 45 siswa. Kelas eksperimen dan kelas kontrol dipilih dengan cara Cluster Sampling, karena peneliti tidak merubah tatanan pengelompokan siswa yang sebelumnya telah ditentukan oleh siswa. Instrumen pengukuran digunakan untuk memperoleh data kemampuan menyimak dan bercerita pada pre-test pada tabel 1.

Instrumen pengukuran dipakai ketika melaksanakan pretest dan posttest penggunaan media Puppet Show terhadap keterampilan menyimak dan bercerita siswa. Menurut (Nurgiyantoro, 2010) untuk mengukur kompetensi bercerita adalah dengan cara menceritakan kembali isi pesan yang terkandung dalam cerita baik secara lisan maupun tertulis. Instrumen ini kemudian divalidasikan dengan teknik validasi ahli selaku dosen Pascasarjana sekaligus pengampu matakuliah pembelajaran yang ahli dalam bidang pembelajaran. Indikator pencapaian yang harus dimiliki peserta didik dalam tes menyimak cerita menurut Nurgiyantoro (2016); Tarigan (2008) yaitu (a) dapat menuliskan tema, (b) dapat memberikan pendapat, (c) dapat membedakan kalimat tanya dan kalimat penjelas, (d) dapat menyebutkan unsur-unsur yang terdapat dalam cerita yang disimak, dan (e) dapat memahami isi cerita. Menurut Moeslichatoen (2004) terdapat enam langkah yang wajib diperhatiakan jika akan bercerita, yakni (a) menjelaskan maksud dan topik dalam aktivitas bercerita, (b) mengatur kursi siswa, (c) membuka aktivitas bercerita, (d) mengembangkan cerita-cerita yang diceriatakan kepada siswa, (e) menentukan metode menyampaikan cerita yang bisa menggungah rasa dalam diri anak, (f) merangsang pemahaman siswa lewat pertanyaan seputar substansi cerita.

Langkah-langkah penggunaan media Puppet Show dalam kemampuan menyimak dan bercerita, yaitu (1) guru mengomunikasikan maksud dan topik aktivitas bercerita kepada siswa, (2) penentuan letak tempat duduk oleh guru yang dibuat kelompok kecil, (3) guru membuka aktivitas bercerita menggunakan Puppet Show, (4) siswa menyimak cerita dari guru dan (5) guru memberikan soal tanya terkait substansi dalam cerita. Langkah-langkah untuk penggunaan media Puppet Show dalam 
kemampuan bercerita, yakni (1) guru mengomunikasikan maksud dan topik dalam kegiatan bercerita kepada siswa, (2) guru mengatur tempat duduk siswa dengan dibuat kelompok kecil, (3) guru membuka kegiatan bercerita menggunakan Puppet Show, (4) siswa menyimak cerita dari guru, (6) guru memberi tugas kepada siswa untuk membuat cerita dialog sendiri, (7) perwakilan kelompok memperagakan untuk bercerita di depan kelas, dan (8) guru memberikan pertanyaan yang berkaitan dengan isi cerita.

Tabel 1. Instrumen Pre-Test dan Post test

\begin{tabular}{|c|c|c|c|c|c|}
\hline Variabel & $\begin{array}{l}\text { Data yang } \\
\text { dikumpulkan }\end{array}$ & $\begin{array}{c}\text { Teknik } \\
\text { Pengumpulan Data }\end{array}$ & Instrumen & Sasaran & Indikator \\
\hline Kemampuan Menyimak & $\begin{array}{l}\text { Kemampuan awal } \\
\text { menyimak siswa yang } \\
\text { diperoleh berupa skor }\end{array}$ & $\begin{array}{l}\text { Tes kemampuan } \\
\text { Menyimak }\end{array}$ & $\begin{array}{l}\text { - Kisi-kisi tes } \\
\text { kemampuan } \\
\text { menyimak } \\
\text { - Rubrik } \\
\text { penilaian tes } \\
\text { kemampuan } \\
\text { bercerita }\end{array}$ & Siswa & $\begin{array}{c}\text { Siswa dapat } \\
\text { Menyimak cerita yang } \\
\text { disampaikan. }\end{array}$ \\
\hline Kemampuan Bercerita & $\begin{array}{l}\text { Kemampuan awal } \\
\text { bercerita siswa yang } \\
\text { diperoleh berupa skor }\end{array}$ & $\begin{array}{l}\text { Tes kemampuan } \\
\text { Bercerita }\end{array}$ & $\begin{array}{l}\text { - Kisi-kisi tes } \\
\text { kemampuan } \\
\text { bercerita } \\
\text { - Rubrik } \\
\text { penilaian tes } \\
\text { kemampuan } \\
\text { bercerita }\end{array}$ & Siswa & $\begin{array}{c}\text { Siswa dapat } \\
\text { bercerita } \\
\text { berdasarkan } \\
\text { cerita yang disampaikan. }\end{array}$ \\
\hline
\end{tabular}

\section{Teknik Pengumpulan Data}

Teknik pengumpulan data yang digunakan adalah observasi dan tes Pelaksanaan pembelajaran di kelas diamati dengan menggunakan lembar observasi keterlaksanaan rentang RPP yang bertujuan untuk mengetahui keterlaksanaan setiap tahap pembelajaran. Instrumen dibuat berdasarkan aspek aspek yang nantinya diukur dan kemudian dikonsultasikan kepada ahli. Firda Ariani, Dawud, I. A. B. (2019) yang mengatakan bahwa untuk melihat hasil dari pemahaman siswa terhadap bahan simakan bisa dilakukan melalui tes tulis dan lisan. Sebelum instrumen dipakai saat penelitian, guna mengetahui kelayakan instrumen, maka dilaksanakan uji kelayakan instrument, yaitu dengan Tingkat kesulitan butir soal ditujukan untuk mengkaji soal mulai dari yang mudah, sedang, sukar, agar proporsi soal dalam suatu tes dapat seimbang. Rumus yang akan digunakan untuk soal obyektif atau pilihan ganda yaitu :

$$
\mathrm{P}=\frac{B}{N}
$$

Sumber: Sugiyono (2013)

Keterangan :

$\mathrm{P}=$ Tingkat kesulitan soal

$\mathrm{B}=$ Banyak siswa yang menjawab butir soal dengan benar

$\mathrm{N}=$ Jumlah siswa yang mengikuti tes

Rumus tersebut kemudian dioperasikan dengan data lapangan, setelah mendapatkan data mentah tersebut, peneliti mengkategorikan pada empat kriteria. Kriteria penentuan taraf kesukaran butir tes ditunjukkan pada tabel 2.

\section{Tabel 2. Kriteria Penentuan Taraf Kesukaran Item Tes}

\begin{tabular}{cl}
\hline Tingkat Kesukaran (\%) & \multicolumn{1}{c}{ Kriteria Kesukaran } \\
\hline$<25$ & Terlalu mudah (tidak baik) \\
$25-75$ & Sedang (baik) \\
$>75$ & Terlalu sulit (tidak baik) \\
\hline
\end{tabular}

Sumber: Purwanto, 2005

Apabila terjadi sebaliknya atau mayoritas kelompok bawah dapat menjawab soal dengan benar maka bisa dikatakan soal berkategori kurang baik atau jelek. Adapun cara penghitungan indeks daya beda tertera di bawah ini. 


$$
\mathrm{D}=\frac{B A}{J A}-\frac{B B}{J B}=P A-P B
$$

Sumber : Sugiyono (2013)

\section{Keterangan :}

$\mathrm{D}$ = Daya beda

$\mathrm{BA}=$ Banyak siswa kelompok atas yang menjawab benar

$\mathrm{BB}=$ Banyak siswa kelompok bawah yang menjawab benar

JA = Banyak siswa kelompok atas

$\mathrm{JB}=$ Banyak siswa kelompok bawah

Setelah peneliti menghitung seberapa beda seluruh soal yang diujikan tersebut, peneliti mengoperasionalkan hasil perhitungan ke dalam pengelompokan yang bermacam-macam. Berikut klasifikasi soal berdasarkan indeks daya beda (Tabel 3).

Tabel 3. Klasifikasi Indeks Daya Beda Soal

\begin{tabular}{ll}
\hline \multicolumn{1}{c}{ Indeks Diskriminasi } & \multicolumn{1}{c}{ Kategori Soal } \\
\hline Lebih dari 0,40 & Sangat Baik, soal diterima \\
$0,30-0,39$ & Baik, soal diterima tetapi perlu perbaikan \\
$0,20-0,29$ & Kurang, soal diperbaiki \\
Kurang dari 0,19 & Jelek, soal tidak terpakai atau dibuang \\
\hline
\end{tabular}

\section{Sumber: Ebel \& Frisbie dalam Sugiyono (2013)}

Validitas digunakan dengan maksud untuk menguji tingkat kevalidan tiap soal dengan memakai rumus korelasi Product Moment. Pengujian validitas ini akan menggunakan taraf signifikansi 0,05, yaitu:

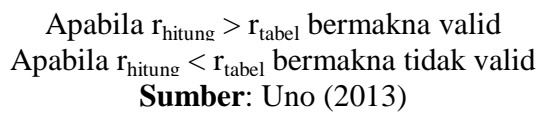

Setelah mendapati setiap soal yang diujikan memenuhi ketentuan validitas, peneliti dapat mengujikan instrumen penelitian tersebut kepada subjek penelitian, yaitu siswa. Apabila hasil hitungan tidak dinyatakan valid, maka peneliti harus melakukan revisi terhadap butir soal dan melakukan validasi di kemudian hari. Reliabilitas digunakan untuk mengetahui keajegan alat tes tersebut dalam penilaian, sehingga apabila digunakan akan memberikan hasil yang relatif sama. Penghitungan dalam penelitian ini akan memakai uji statistik Cronbach's alpha $(\alpha)$ dan dioperasikan pada SPSS 25 yang digunakan peneliti. Kriteria untuk mengetahui reliabilitas instrumen ditunjukkan pada tabel 4.

\section{Tabel 4. Kriteria Reliabilitas Soal}

\begin{tabular}{ccl}
\hline No & Indeks Diskriminasi & Kategori Soal \\
\hline 1. & $0,00-0,20$ & Sangat rendah \\
2. & $0,21-0,40$ & Sedang \\
3. & $0,41-0,60$ & Cukup \\
4. & $0,61-0,80$ & Tinggi \\
5. & $0,81-1,00$ & Sangat Tinggi \\
\hline
\end{tabular}

\section{Sumber: Arikunto (2013)}

Instrumen tes yang diujikan kepada setiap siswa haruslah sama dan tidak boleh berbeda, sehingga hasilnyapun tidak akan melenceng dari hipotesis penelitian. Apabila dalam pengujian reliabilitas soal peneliti tidak mendapatkan kriteria tinggi ataupun sangat tinggi, maka pada hasil penelitian juga perlu dinyatakan bahwa keajegkan penelitian ini pada kriteria yang mana.

\section{Teknik Analisis Data}

Penelitian yang dilakukan ialah jenis kuantitatif sehingga teknik analisis data yang akan digunakan yaitu menggunakan statistik. Dalam menganalisis data terdapat tiga macam pengujian, yaitu normalitas, homogenitas, hipotesis memakai manova, dan berikut penjelasannya. 


\section{Uji Normalitas}

Uji normalitas dilaksanakan dengan tujuan guna melihat data yang didapat apakah normal atau tidak. Pengujian memakai uji Kolmogrov Seminorv berbantuan aplikasi SPSS. Kriteria pengujian yang akan digunakan yaitu, apabila nilai signifikansi $>0,05$, data akan dinyatakan berdistribusi normal, sedangkan apabila nilai signifikansi $<0,05$ maka data dinyatakan berdistribusi tidak normal.

\section{Uji Homogenitas}

Uji homogenitas dilakukan dengan tujuan guna mengetahui kesamaan atau perbedaan dari sampel. Pada uji homogenitas, peneliti memakai uji Levene's Test berbantuan aplikasi SPSS. Kriteria pengujian yang akan digunakan yakni, apabila nilai probabilitas $>0,05$, sampel mempunyai varian sama dan apabila probabilitas $<0,05$, sampel mempunyai varian tidak sama.

\section{Uji Hipotesis}

Data yang didapatkan dari hasil post tes akan digunakan guna mengetahui pengaruh media Puppet Show terhadap kemampuan menyimak dan bercerita siswa setelah diberikannya penerapan yang berbeda antara kelas eksperimen dan kontrol. Data diolah dengan menggunakan analisis statistik yaitu Manova dengan berbantuan SPSS dengan ketentuan berikut.

$$
\begin{gathered}
\mathrm{H}_{0}: \theta=\theta_{0} \\
\mathrm{H}_{1}: \theta>\theta_{0} \text { atau } \mathrm{H}_{1}: \theta<\theta_{0}
\end{gathered}
$$

Sumber: Sugiyono (2013)

Rumus tersebut diartikan apabila signifikansi < probabilitas $(0,05)$ dimaknai terdapat pengaruh dalam penggunaan media puppet show terhadap kemampuan menyimak dan bercerita siswa. Sementara itu, apabila signifikansi $>$ probabilitas $(0,05)$ dimaknai tidak terdapat pengaruh dalam penggunaan media puppet show terhadap kemampuan menyimak dan bercerita siswa.

\section{HASIL}

Deskripsi data pada penelitian ini yaitu data kemampuan awal (pretest) dan hasil belajar (posttest). Subyek penelitian terbagi atas kelompok eksperimen dengan media puppet show dan kelompok kontrol tanpa media puppet show. Analisis deskriptif dalam penelitian ini berguna untuk menyajikan data sehingga data mudah untuk diinterprestasi dalam bentuk tabel, besara nilai mean, standar deviasi, nilai minimum, dan frekuensi.

\section{Kemampuan Awal Siswa}

Deskripsi data pada penelitian ini yaitu data kemampuan awal siswa (pre test) dan hasil belajar siswa (post test). Penelitian ini dilaksanakan terhadap subyek yang dibagi dalam dua kelompok, yaitu kelompok eksperimen dengan perlakuan menggunakan media puppet show dan kelompok kontrol dengan pembelajaran seperti biasanya. Pada penelitian ini juga mengumpulkan data motivasi berprestasi siswa yang terbagi atas motivasi tinggi dan motivasi rendah. Analisis deskriptif dalam penelitian ini berguna untuk menyajikan data sehingga data mudah untuk diinterprestasi dalam bentuk tabel, besaran nilai mean, standar deviasi, nilai minimum, nilai maksimum, dan frekuensi.

Pretest dilaksanakan guna menganalisis kemampuan awal siswa. Pretes dilaksanakan dengan menggunakan soal yang diambilkan dari kisi-kisi dan telah diuji validitas maupun reliabilitasnya, sehingga telah sesuai dengan ketentuan soal yang baik. Setelah dilakukan kegiatan pretes pada siswa kelompok eksperimen dan siswa kelompok kontrol (hasil terlampir), rekapitulasi nilai hasil pretes pada kelompok eksperimen dan kelompok kontrol dapat dilihat pada tabel 5. berikut.

\section{Tabel 5. Data Rekapitulasi Nilai Pre-Tes Siswa}

\begin{tabular}{cccc}
\hline No & Data & Kelompok Kontrol & Kelompok Eksperimen \\
\hline 1. & Jumlah Siswa & 22 & 23 \\
2. & Nilai Terendah & 30 & 40 \\
3. & Nilai Tertinggi & 100 & 100 \\
\hline & Rata-rata Kelas & 67,85 & 69,06 \\
\hline
\end{tabular}

Menurut data di atas, dapat dijelaskan nilai rerata pretes kelompok kontrol yakni 68,75 dengan nilai minimum 30 dan nilai maksimum 100, sedangkan nilai rerata pre-tes kelompok eksperimen yakni 69,06 dengan nilai minimum 40 dan nilai maksimum 100. Berdasarkan data nilai pre tes di atas, kedua kelompok penelitian memiliki selisih rata-rata kelas sebesar 1,21. 


\section{Paparan Data Post-test Penelitian}

Deskripsi data hasil belajar pada penelitian ini meliputi: (1) deskripsi data keterampilan menyimak siswa yang diajar dengan menggunakan media puppet show dan tanpa media puppet show, (2) deskripsi data keterampilan berbicara siswa dengan media puppet show dan tanpa media puppet show. Adapun deskripsi data pada penelitian ini sebagai berikut.

Deskripsi Data Kemampuan Menyimak Siswa

Media yang dipakai dalam memberikan perlakuan yaitu media puppet show. Puppet show digunakan pada kelas eksperimen (2A) dan pembelajaran tanpa media puppet show digunakan pada kelas kontrol (2B). Ringkasan data keterampilan menyimak siswa berdasarkan variasi media pembelajaran ditampilkan pada table 6 .

Tabel 6. Ringkasan Data Hasil Keterampilan Menyimak Siswa

\begin{tabular}{lccccc}
\hline \multicolumn{1}{c}{ Hasil Belajar } & N & Nilai Terendah & Nilai Tertinggi & Mean & Std. Deviasi \\
\hline Kelompok Kontrol & 23 & 60 & 96 & 77,42 & 9,315 \\
Kelompok Eksperimen & 22 & 64 & 96 & 82,50 & 9,016 \\
\hline
\end{tabular}

Sumber: Pengolahan Data Penelitian (2019)

Data di atas menunjukkan perbandingan nilai terendah, nilai tertinggi, dan mean. Hasil belajar terendah siswa yang diajar menggunakan media pupper show sebesar 64, sedangkan hasil belajar terendah siswa yang diajar tanpa menggunakan media pupper show sebesar 60 .

\section{Deskripsi Data Kemampuan Bercerita Siswa}

Berikut ini adalah deskripsi dari keterampilan bercerita siswa pada kelompok eksperimen dengan penerapan media puppet show dan kelompok kontrol dengan pembelajaran seperti biasanya.

Tabel 7. Data Keterampilan Bercerita Siswa

\begin{tabular}{lccccc}
\hline Kelompok Penelitian & $\mathbf{N}$ & Nilai Terendah & Nilai Tertinggi & Mean & Standar Deviasi \\
\hline Kontrol & 23 & 60 & 80 & 69,84 & 5,565 \\
Eksperimen & 22 & 64 & 96 & 77,26 & 7,665 \\
\hline
\end{tabular}

Sumber: Pengolahan Data Penelitian (2019).

Berdasarkan data di atas, kemampuan berbicara siswa kelompok eksperimen lebih bagus daripada keterampilan berbicara pada kelompok kontol. Nilai rerata siswa yang memiliki motivasi pada kelompok eksperimen yakni 77,26 dengan nilai minimum 64 dan maksimum 96.

\section{Analisis Uji Prasyarat Penelitian}

Sebelum dilaksanakan uji hipotesis dengan Uji T, maka dilaksanakan uji prasyarat terlebih dahulu yaitu uji normalitas dan uji homogenitas. Uji prasarat dilakukan guna melihat apakah data memenuhi persyaratan untuk dilaksanakan uji parametrik. Adapun penjelasan dari pengujian prasyarat dipaparkan di bawah ini.

\section{Uji Normalitas Sebaran Data}

Uji normalitas dilaksanakan guna melihat sampel yang dipakai berasal dari populasi dengan distribusi normal atau tidak. Uji normalitas memakai uji kolmogorov-smirnov dengan taraf sig. 5\%. (sig > 0,05). Namun apabila nilai kolmogorov-smirnov memiliki signifikasi kurang dari 0,05 (Sig < 0,05), sebaran data tidak terdistribusi secara normal. Data yang diuji normalitas adalah data pretes dan postest, berikut dipaparkan pada tabel 8.

Tabel 8. Hasil Uji Normalitas Menyimak pada Kelas Kontrol

\begin{tabular}{cccccc}
\hline \multicolumn{5}{c}{ Tests of Normality } \\
\hline & Kolmogorov-Smirnov ${ }^{\text {a }}$ & \multicolumn{3}{c}{ Shapiro-Wilk } \\
\cline { 2 - 6 } & Statistic & df & Sig. & Statistic & Df Sig. \\
\hline pre_tes & .171 & 20 & .129 & .963 & 20.602 \\
\hline post_tes & .120 & 20 & $.200^{*}$ & .950 & 20.373 \\
\hline
\end{tabular}




\begin{tabular}{|c|c|c|c|c|c|}
\hline \multicolumn{6}{|c|}{ Tests of Normality } \\
\hline & \multicolumn{3}{|c|}{ Kolmogorov-Smirnov ${ }^{\text {a }}$} & \multicolumn{2}{|c|}{ Shapiro-Wilk } \\
\hline & Statistic & df & Sig. & Statistic & Df Sig. \\
\hline pre_tes & .171 & 20 & .129 & .963 & 20.602 \\
\hline post_tes & .120 & 20 & $.200^{*}$ & .950 & 20.373 \\
\hline \multicolumn{6}{|c|}{ a. Lilliefors Significance Correction } \\
\hline \multicolumn{6}{|c|}{ *. This is a lower bound of the true significance. } \\
\hline
\end{tabular}

Sumber: Pengolahan Data Penelitian SPSS 25.0 (2019)

Tabel 9. Hasil Uji Normalitas Bercerita pada Kelas Kontrol

\begin{tabular}{|c|c|c|c|c|c|}
\hline \multicolumn{6}{|c|}{ Tests of Normality } \\
\hline & \multicolumn{3}{|c|}{ Kolmogorov-Smirnov ${ }^{a}$} & \multicolumn{2}{|c|}{ Shapiro-Wilk } \\
\hline & Statistic & df & Sig. & Statistic & Df Sig. \\
\hline pre_tes & .147 & 20 & $200^{*}$ & .940 & 20.235 \\
\hline post_tes & .173 & 20 & .119 & .917 & 20.089 \\
\hline \multicolumn{6}{|c|}{ a. Lilliefors Significance Correction } \\
\hline \multicolumn{6}{|c|}{ *. This is a lower bound of the true significance. } \\
\hline
\end{tabular}

\section{Sumber: Pengolahan Data Penelitian SPSS 25.0 (2019)}

Menurut hasil pengujian pada tabel 8.1 dan 8.2 bisa diketahui bahwa nilai sig. kemampuan menyimak pretes yakni senilai 0,129 , posttest dan nilai sig. pada postes senilai 0,200 . Sedangkan kemampuan berbicara pretest senilai 0,200 dan posttest senilai 0,119. Dikarenan semua nilai nig, >0,05 maka data berdistribusi normal.

Tabel 10. Hasil Uji Normalitas pada Kelas Eksperimen

\begin{tabular}{|c|c|c|c|c|c|}
\hline \multicolumn{6}{|c|}{ Tests of Normality } \\
\hline & \multicolumn{3}{|c|}{ Kolmogorov-Smirnov ${ }^{a}$} & \multicolumn{2}{|c|}{ Shapiro-Wilk } \\
\hline & Statistic & df & Sig. & Statisti & df Sig. \\
\hline Pre_tes & .143 & 21 & $.200^{*}$ & .921 & 21.090 \\
\hline Pos_tes & .156 & 21 & .196 & .958 & 21.480 \\
\hline a. Lillief & rs Significa & ee $\mathrm{C}$ & rection & & \\
\hline
\end{tabular}

Sumber: Pengolahan Data Penelitian SPSS 25.0 (2019)

Tabel 11. Hasil Uji Normalitas pada Kelas Eksperimen

\begin{tabular}{|c|c|c|c|c|c|}
\hline \multicolumn{6}{|c|}{ Tests of Normality } \\
\hline & \multicolumn{3}{|c|}{ Kolmogorov-Smirnov $^{a}$} & \multicolumn{2}{|c|}{ Shapiro-Wilk } \\
\hline & Statistic & df & Sig. & Statistic & df Sig. \\
\hline Pre_tes & .175 & 21 & .094 & .954 & 21.412 \\
\hline Pos_tes & .124 & 21 & $200^{*}$ & .957 & 21.453 \\
\hline a. Lillief & Sionific & & Therios & & \\
\hline
\end{tabular}

Sumber: Pengolahan Data Penelitian SPSS 25.0 (2019).

Menurut hasil pengujian pada tabel 9 dapat diketahui bahwa nilai sig. Kemampuan menyimak pretes senilai 0,094, posttest dan nilai sig. pada postes senilai 0,200 . Sedangkan kemampuan berbicara pretest senilai 0,200 dan posttest senilai 0,196. Dikarena semua nilai nig, > 0,05 maka data berdistribusi normal. Uji homogenitas dilaksanakan guna melihat variansi 
pada subjek penelitian yakni bersifat homogen atau tidak. Pengujian homogenitas yang dipakai ialah lavenne's statistic, dengan taraf sig. 5\% (sig > 0,05). Uji homogentias meliputi data pretest dan posttest dari kelompok kontrol. Data pengujian dipaparkan pada tabel 12 .

Tabel 12. Hasil Uji Normalitas Pada Kelas Eksperimen

\begin{tabular}{ccccc}
\hline & Test of Homogeneity of Variances \\
\hline Kemampuan & Levene Statistic & df1 & df2 & Sig. \\
\hline Berbicara & 0.732 & 1 & 38 & .397 \\
Menyimak & 2.893 & 1 & 38 & .097 \\
\hline
\end{tabular}

Sumber : Pengolahan Data Penelitian SPSS 25.0 (2019)

Menurut data pengujian seperti yang tertera pada tabel di atas dapat diketahui nilai sig. kemampuan berbicara yang didapatkan senilai 0,895 dan menyimak senilai 0,097. Karena semua nilai sig. > 0,05 maka data bersifat homogen.

Tabel 13. Hasil Uji Normalitas Pada Kelas Eksperimen

\begin{tabular}{ccccc}
\hline & \multicolumn{4}{c}{ Test of Homogeneity of Variances } \\
\hline Kemampuan & Levene Statistic & df1 & df2 & Sig. \\
\hline Berbicara & 2.585 & 1 & 40 & .116 \\
Menyimak & 3.229 & 1 & 40 & .080 \\
\hline
\end{tabular}

Sumber: Pengolahan Data Penelitian SPSS 25.0 (2019)

Menurut data pengujian seperti yang tertera pada tabel di atas bisa diketahui nilai sig. kemampuan berbicara yang didapatkan ialah senilai 0,116 dan menyimak senilai 0,080. Karena semua nilai sig. > 0,05 maka data bersifat homogen. Jadi, dapat dikatakan bahwa data yang diperoleh homogen atau asumsi homogenitas terpenuhi sehingga dapat dilanjutkan untuk uji selanjutnya.

\section{Analisis Uji Hipotesis Penelitian}

Setelah dipastikan data berdistribusi normal dan varian data homogen, maka selanjutnya data diuji hipotesisnya dengan menggunakan manova. Adapun hasil-hasil dari uji manova dapat dilihat pada tabel 14-16.

Tabel 14. Descriptive Statistics

\begin{tabular}{ccccc}
\hline Media & \multicolumn{3}{c}{ Mean Std. Deviation N } \\
\hline Menyimak & Pupet show & 24.43 & 4.578 & 21 \\
& konvensional & 20.15 & 4.209 & 20 \\
& Total & 22.34 & 4.856 & 41 \\
\hline Bercerita & Pupet show & 23.05 & 3.930 & 21 \\
& konvensional & 17.75 & 3.370 & 20 \\
& Total & 20.46 & 4.506 & 41 \\
\hline
\end{tabular}

Sumber: Pengolahan Data Penelitian SPSS 25.0 (2019)

Menurut data di atas diketahui nilai mean kemampuan menyimak dengan media puppet show senilai 24,43 pada kelompok eksperimen, sedangkan pada kelompok kontrol mendapatkan mean sebesar 20,15. Kemampuan bercerita pada kelas eksperimen mendapatkan mean 23,05, sedangkan kelas kontrol mendapatkan 17,75. Standar deviasi keterampilan menyimak siswa mendapatkan nilai 4,578 pada kelas eksperimen, sedangkan pada kelas kontrol mendapatkan nilai 4,209. Standar deviasi bercerita kelas eksperimen nilai 3,930, sedangkan kelas kontrol sebesar 3,370. 
Tabel 15. Multivariate Tests ${ }^{b}$

\begin{tabular}{llccccc}
\hline & Effect & Value & F & Hypothesis df & Error df & Sig. \\
\hline Intercept & Pillai's Trace & .971 & $626.230^{\mathrm{a}}$ & 2.000 & 38.000 & .000 \\
& Wilks' Lambda & .029 & $626.230^{\mathrm{a}}$ & 2.000 & 38.000 & .000 \\
& Hotelling's Trace & 32.959 & $626.230^{\mathrm{a}}$ & 2.000 & 38.000 & .000 \\
& Roy's Largest Root & 32.959 & $626.230^{\mathrm{a}}$ & 2.000 & 38.000 & .000 \\
\hline Metode & Pillai's Trace & .378 & $11.525^{\mathrm{a}}$ & 2.000 & 38.000 & .000 \\
& Wilks' Lambda & .622 & $11.525^{\mathrm{a}}$ & 2.000 & 38.000 & .000 \\
& Hotelling's Trace & .607 & $11.525^{\mathrm{a}}$ & 2.000 & 38.000 & .000 \\
& Roy's Largest Root & .607 & $11.525^{\mathrm{a}}$ & 2.000 & 38.000 & .000 \\
\hline
\end{tabular}

a. Exact statistic

b. Design: Intercept + Metode

Sumber: Pengolahan Data Penelitian SPSS 25.0 (2019).

Berdasarkan uji Hotelling's Trace pada tabel 14 di atas didapatkan nilai sig. senilai 0,000 yang artinya terdapat pengaruh signifikan penggunaan media puppet show terhadap kemampuan bercerita pada siswa kelas II SDN 01 Wonomulyo.

Tabel 16. Tests of Between-Subjects Effects

\begin{tabular}{|c|c|c|c|c|c|c|}
\hline Source & Dependent Variable T & Type III Sum of Square & s df & Mean Square & $\mathbf{F}$ & Sig. \\
\hline \multirow[t]{2}{*}{ Corrected Model } & Menyimak & $187.527^{\mathrm{a}}$ & 1 & 187.527 & 9.678 & .003 \\
\hline & Bercerita & $287.493^{\mathrm{b}}$ & 1 & 287.493 & 21.369 & .000 \\
\hline \multirow[t]{2}{*}{ Intercept } & Menyimak & 20357.185 & 1 & 20357.185 & 1050.599 & 9.000 \\
\hline & Bercerita & 17050.420 & 1 & 17050.420 & 1267.321 & 1.000 \\
\hline \multirow[t]{2}{*}{ Metode } & Menyimak & 187.527 & 1 & 187.527 & 9.678 & .003 \\
\hline & Bercerita & 287.493 & 1 & 287.493 & 21.369 & .000 \\
\hline \multirow[t]{2}{*}{ Error } & Menyimak & 755.693 & 39 & 19.377 & - & - \\
\hline & Bercerita & 524.702 & 39 & 13.454 & & \\
\hline \multirow[t]{2}{*}{ Total } & Menyimak & 21408.000 & 41 & - & - & - \\
\hline & Bercerita & 17981.000 & 41 & & & \\
\hline \multirow[t]{2}{*}{ Corrected Total } & Menyimak & 943.220 & 40 & - & - & - \\
\hline & Bercerita & 812.195 & 40 & & & \\
\hline
\end{tabular}

a. $\mathrm{R}$ Squared $=.199$ (Adjusted R Squared $=.178$ )

b. R Squared $=.354$ (Adjusted R Squared $=.337$ )

Sumber: Pengolahan Data Penelitian SPSS 25.0 (2019)

Berdasarkan tabel di atas pada Tests of Between-Subjects Effects diperoleh nilai sig. Bercerita $=0,03$ dan menyimak $=$ 0, 00. Karena nilai sig. $<0,05=$ media Puppet Show berpengaruh signifikan terhadap kemampuan bercerita dan menyimak pada kelas eksperimen. Berdasarkan hasil pengujian di atas, dipaparkan rumusan di bawah ini.

Pertama, media puppet show berpengaruh signifikan terhadap kemampuan menyimak. Terbukti dengan perolehan nilai sig.senilai $0,03<0,05$. Kedua, media puppet show berpengaruh signifikan terhadap kemampuan bercerita. Terbukti dengan perolehan nilai sig. senilai $0,00<0,05$. Ketiga, media puppet show berpengaruh signifikan terhadap kemampuan menyimak dan bercerita. Terbukti dengan perolehan nilai sig. senilai $0,000<0,05$. 


\section{PEMBAHASAN}

Berdasarkan tabel 4.10 bab iv penelitian ini pada tests of between-subjects effects diperoleh nilai signifikansi bercerita = 0,03 dan menyimak $=0,00$. Karena nilai sig. $<0,05$ dapat diartikan media puppet show berpengaruh signifikan terhadap kemampuan bercerita dan menyimak pada kelas eksperimen, yaitu lebih kecil daripada 0,005 yang artinya terdapat pengaruh signifikan penggunaan media puppet show terhadap kemampuan menyimak dan bercerita pada siswa kelas II SD.

\section{Pengaruh Media Puppet Show terhadap Kemampuan Menyimak Siswa Kelas II Sekolah Dasar}

Hasil riset (Widowati, 2016) menyimpulkan pemakaian boneka tangan dalam kegiatan KBM dapat memunculkan ketertarikan siswa sehingga siswa dapat termotivasi untuk mengikuti proses KBM. Pemakaian boneka tangan yang dilakukan secara lisan dapat mengonkritkan pengetahuan siswa sehingga siswa lebih mudah dalam menyerap materi yang disampaikan. Oleh sebab itu, disimpulkan bahwa pemakaian boneka tangan mempunyai dampak positif terhadap keterampilan menyimak cerita siswa kelas II SDN Margoyasan. Peneliti lain, Apriani (2018) menyatakan hasil pengujian data posttest hasil keterampilan menyimak cerita terhadap uji $\mathrm{t}$ dengan $\alpha=0,05$ diperoleh thitung $>$ ttabel $(2,586>2,013)$ sehingga $\mathrm{H}_{0}$ ditolak. Hal demikian artinya terdapat perbedaan hasil keterampilan menyimak siswa. Sama dengan penelitian oleh (Septiadi, I.G.A, Ni Wayan Arini, 2014) yang meneliti strategi mendengarkan langsung dalam pengaruhnya terhdap kemampuan menyimak siswa kelas IV SD. Hasilnya menunjukkan thitung=8,13 > ttabel=2,021. Hal ini menunjukkan adanya perbedaan keterampilan menyimak secara signifikan antara siswa. Dari ketiga penelitian ini mendukung hasil penelitian yang dilakukan peneliti yang menyatakan adanya pengaruh media pembelajaran terhadap kemampuan menyimak siswa kelas II SD.

Penggunaan media puppet show berpengaruh terhadap kemampuan menyimak siswa pada strata kelas yang lain, misalnya kelas I SD. Bahkan pengaruhnya signifikan terhadap kemampuan kelas I SD dalam menyimak. Dilihat dari peneliti sebelumnya menurut (Andriani, 2017) menyatakan bahwa (1) kemampuan mendongeng siswa menggunakan boneka tangan di atas KKM; (2) ada perbedaan kemampuan menyimak dongeng siswa antara yang diterapkan dengan boneka tangan dan tanpa boneka tangan; (3) ada pengaruh yang signifikan media boneka tangan terhadap kemampuan menyimak dongeng siswa. Peneliti dalam hal ini tidak menguji signifikansi penggunaan media puppet show, namun hanya untuk mengetahui terdapat pengaruh atau tidaknya penggunaan media pada kemampuan menyimak siswa.

Peneliti lain menyajikan hal berbeda dengan sebelumnya, seperti halnya pada penelitian (Kök, 2018) dan (Bulut \& Ertem, 2018) yang meneliti tentang model mendengarkan komprehensif pada siswa sekolah dasar dan pengaruhnya terhadap kemampuan menyimak siswa. Hasil dari kedua penelitian ini secara data kuantitatif menunjukkan adanya pengaruh positif terhadap kemampuan siswa dalam menyimak cerita, dan secara kualitatif digambarkan kemampuan anak yang secara luas memahami maksud dari cerita tersebut. kedua penelitian ini menyatakan bercerita secara komprehensif dalam hal ini dilakukan dengan media boneka tangan akan meningkatkan kemampuan siswa dalam menyimak.

\section{Pengaruh Media Puppet Show terhadap Kemampuan Bercerita Siswa Kelas II Sekolah Dasar}

Didukung juga penelitian Rosidah (2017) dengan kesimpulan adanya pengaruh penggunaan media boneka tangan terhadap keterampilan bercerita anak usia 4-5 tahun TK Dharma Wanita Persatuan Randuagung. Disimpulkan bahwa penggunaan media boneka tangan berpengaruh terhadap keterampilan bercerita anak kelompok A. Pada jenjang sekolah dasar, (Mariana \& Zubaidah, 2015) meneliti pengaruh penggunaan media boneka tangan terhadap keterampilan bercerita siswa kelas V SD Se-Gugus 4 Kecamatan Bantul. Hasilnya ditemukan dampak yang signifikan dan baik pada keterampilan bercerita siswa dengan menggunakan media boneka tangan.

Adanya kontrbusi riset-riset ini dapat berdamapak bagi output belajar anak. Winkel (Purwanto, 2011) hasil belajar adalah perubahan yang mengakibatkan manusia berubah dalam sikap dan tingkah lakunya. Aspek perubahan itu mengacu pada taksonomi tujuan pengajaran yang dikembangkan oleh Bloom, Simpson, dan Harrow mencakup aspek kognitif, afektif, dan psikomotorik". Hal ini dilakukan agar pemahaman dan penerimaan topik pengajaran dapat diterima oleh siswa dengan mudah. Penelitan oleh (Septiyani \& Kurniah, 2017) dan (Nugraha, 2017) menyatakan bahwa penggunaan media boneka dapat meningkatkan kemampuan siswa dalam bercerita, baik pada muatanm bahasa Indonesia itu sendiri maupun konsep materi lainnya. Kesimpulanya, hasil belajar ialah hasil akhir yang didapatkan seseorang setelah melakukan upaya belajar. Hasil belajar ialah munculnya perbedaan tingkah laku seseorang yang mencakup aspek pengetahaun, sikap, dan keterampilan yang didapatkan sesudah seseorang melakukan aktivitas belajarnya sesudah berinteraksi dengan berbagai bahan dan referensi untuk belajar.

\section{Pengaruh Media Puppet Show terhadap Kemampuan Menyimak dan Bercerita Siswa Kelas II Sekolah Dasar}

Seperti yang diungkapkan oleh Degeng (2011) guna menciptakan kondisi yang menyenangkan, perlu adanya upaya membangkitkan dorongan, minat, rasa saling memahami, rasa saling menghargai, mengonstruksi suasana kegembiraraan dan memacu keingintahuan serta sikap keteladanan. Belajar diibaratkan seperti air sungai yang mengalir secara berkesinambungan, penuh tantangan yang didalamnya ada kesalahan, inovasi, dan ketakjuban memenuhi tempat tersebut. Penelitian oleh (Sri Ustari, 
2018) adanya ketidaksamaan keterampilan berbicara bahasa Indonesia antara kelompok siswa yang dibelajarkan dengan model pembelajaran dramtic learning berbantuan boneka tangan dengan kelompok siswa yang dibelajarkan dengan pembelajaran konvensional pada siswa kelas III SD di Gugus III Kecamatan Busungbiu tahun pelajaran 2017/2018. Penelitian oleh (Altun, 2018) dengan penelitiannya tentang media multimedia stories dalam meningkatkan kemampuan menyimak dan bercerita siswa. Hasil penelitian ini menunjukkan cerita berbasis media multimedia dapat menumbuhkan pemahaman cerita implisit anak-anak dan pemikiran inferensial tentang isi cerita, dan dampaknya dapat meningkatkan kedua kemampuan siswa tersebut.

Penelitian oleh (Maureen, van der Meij, \& de Jong, 2018) yang bervariabel literasi digital, kemampuan menyimak dan bercerita yang menjelaskan teknik sembilan event Gagné adalah pendekatan yang menjanjikan untuk meningkatkan pengembangan literasi dan literasi digital di ruang kelas anak usia dini. Sesuai dengan prinsip Gagne, peneliti menyimpulkan adanya pengaruh positif antara media pembelajaran yang menarik terhdap kemampuan menyimak dan bercerita siswa, utamanya pada kelas rendah. Serupa dengan hasil penelitian yang dilakukan peneliti, peneliti menggunakan media yang menarik berupa puppet show dan hasilnya berpengaruh terhadap kemampuan menyimak dan bercerita siswa. Meskipun anak tersebut dalam kondisi ekonomi kurang kuat, seperti lokasi penelitian di SDN Wonomulyo 01 dengan latar belakang ekonomi yang lemah. Hal ini ditunjukkan dengan penelitian (Kusdiyati, 2018) yang menyatakan pemberian dongeng dengan boneka tangan memiliki pengaruh terhadap kemampuan berbahasa Indonesia anak dari status sosial ekonomi rendah pada siswa.

Selain dalam fokus kemampuan siswa dalam menyimak dan bercerita yang ditingkatkan melalui boneka tangan, penelitian lain mengungkapkan kegunaan kemampuan ini dalam kehidupan keseharian siswa di masa sekarang maupun mendatang. Seperti penelitian (Whiteland, 2016); (Susan, 2016); (Dunst, 2012) yang menyatakan bercerita dengan boneka tangan sangat memengaruhi kehidupan siswa di masa mendatang dan sekarang, keduanya itu akan ditingkatkan melalui kemampuan berbahasanya, termasuk dalam menyimak dan berbicara. Sama halnya dengan riset peneliti yakni kemampuan menyimak dan bercerita juga dapat ditingkatkan dengan boneka tangan yang bermanfaat kedepannya. Didukung dengan penelitian (Fakhrudin \& Inayati, 2015) yang memakai media puppet show dalam storytelling, hasilnya media puppet show layak dan efektif digunakan dalam pembelajaran, utamanya dalam pembelajaran bahasa Indonesia.

\section{SIMPULAN}

Peneliti memberikan kesimpulan berdasarkan hasil penelitian dan diperkuat pada pembahasan yang kemudian ditemukanlah benang merah dalam penelitian ini. Berikut merupakan kesimpulan penelitian yang diperoleh peneliti sesuai dengan rumusan masalah penelitian. Pertama, media puppet show berpengaruh signifikan terhadap kemampuan menyimak. Terbukti dengan perolehan nilai sig, senilai $0,03<0,05$. Kedua, Media puppet show berpengaruh signifikan terhadap kemampuan bercerita. Terbukti dengan perolehan nilai sig. senilai $0,00<0,05$. Ketiga, media puppet show berpengaruh signifikan terhadap kemampuan menyimak dan bercerita. Terbukti dengan perolehan nilai sig. senilai $0,000<0,05$.

Adapun saran yang dapat diberikan oleh peneliti kepada guru, kepala sekolah, siswa, dan peneliti lain. Bagi guru, Diharapkan guru dapat memberikan kontrol kepada siswa saat pelaksanaan KBM. Pembelajaran yang aktif dan interaktif terkadang sulit dikontrol. Oleh karena itu, penggunaan media puppet show perlu disertai dengan keiukutsertaan guru untuk menjaga konduksivitas kelas. Bagi kepala sekolah, diharapkan lebih memberikan semangat dan dorongan pada guru dalam pelaksanaan pembelajaran di sekolah sehingga guru lebih kreatif dalam mengemas pembelajaran di luar seperti yang sudah dilaksanakan peneliti menggunakan media pembelajaran interaktif. Bagi siswa, diharapkan dengan diterapkannya media puppet show pada proses pembelajaran, dapat memunculkan ketertarikan siswa pada kegiatan KBM. Dengan kondisi yang positif tersebut, siswa nantinya dapat menguasai hal yang dipelajari dengan maksimal sehingga prestasi belajar mereka akan lebih baik. Bagi peneliti lain, hasil riset ini dapat dipakai sebagai pengalaman dalam menerapkan pembelajaran dengan media puppet show pada siswa SD.

\section{DAFTAR RUJUKAN}

Altun, D. (2018). The Efficacy of Multimedia Stories in Preschoolers' Explicit and Implicit Story Comprehension. Early Childhood Education Journal, 46(6), 629-642. https://doi.org/10.1007/s10643-018-0916-8

Ariani, F., Dawud., \& Basuki, I. A. (2019). Korelasi Kemampuan Bernalar dengan Kemampuan Menyimak Kritis Debat pada Siswa Kelas X. Jurnal Pendidikan: Teori, Penelitian, dan Pengembangan, 4(3), 230-234.

Bachri, B. S. (2005). Pengembangan Kegiatan Bercerita di Taman Kanak-kanak, Teknik dan Prosedurnya.

Bulut, B., \& Ertem, İ. S. (2018). A Think-Aloud Study: Listening Comprehension Strategies Used by Primary School Students. Journal of Education and Training Studies, 6(5), 135. https://doi.org/10.11114/jets.v6i5.3050

Chrisyarani, D. D. (2018). Pengembangan Media Boneka Tangan dengan Metode Bercerita untuk Siswa Kelas V SDN Sudimoro 2 Kabupaten Malang. Jurnal Bidang Pendidikan Dasar (JBPD), 2(1), 57-62.

Dunst, C. J. (2012). Effects of Puppetry on Elementary Students' Knowledge of and Attitudes Toward Individuals with Disabilities. International Electronic Journal of Elementary Education, 4(3), 451-457. 
Fakhrudin, A. \& Inayati, A. (2015). Pengembangan Media Boneka Tangan padaTema Lingkungan Kelas II SD Negeri 02 Medayu Kabupaten Pemalang. Prosiding Seminar Nasional Pendidikan, 80-85.

Fatimah, N. (2015). Implementasi Cooperative Learning Tipe Think-Pair-Share dalam Pembelajaran Bercerita di Sekolah Menengah Pertama. Jurnal Penelitian Humaniora, 16(4), 90-98.

Kök, İ. (2018). Relationship between Listening Comprehension Strategy Use and Listening Comprehension Proficiency. International Journal of Listening, 32(3), 163-179. https://doi.org/10.1080/10904018.2016.1276457

Kusdiyati, S. (2018). Pengaruh Pemberian Dongeng Dengan Boneka Tangan Terhadap Kemampuan Berbahasa Indonesia. Psympathic: Jurnal Ilmiah Psikologi, 3(2), 157-168. https://doi.org/10.15575/psy.v3i2.2184

Mariana, S., \& Zubaidah, E. (2015). Pengaruh Penggunaan Media Boneka Tangan terhadap Keterampilan Bercerita Siswa Kelas V Sd Se-Gugus 4 Kecamatan Bantul. Jurnal Prima Edukasia, 3(2), 166. https://doi.org/10.21831/jpe.v3i2.6538

Maureen, I. Y., van der Meij, H., \& de Jong, T. (2018). Supporting Literacy and Digital Literacy Development in Early Childhood Education Using Storytelling Activities. International Journal of Early Childhood, 50(3), 371-389. https://doi.org/10.1007/s13158-018-0230-z

Mulyati, Y. (2009). Pembelajaran Bahasa Indonesia yang Berorientasikan dalam Perspektif Pendidikan. Bandung: Jurusan Pendidikan Bahasa dan Sastra Indonesia FPBS UPI.

Nugraha, A. S. (2017). Peningkatan Kemampuan Bercerita Program Studi Pendidikan Bahasa dan Sastra Indonesia Tahun Pelajaran 2016 / 2017. LITERASI: Jurnal Ilmiah Pendidikan Bahasa, Sastra Indonesia dan Daerah, 7(2), $153-159$. http://dx.doi.org/10.23969/literasi.v7i2.535.

Nurgiyantoro, B. (2010). Penilaian Pembelajaran Bahasa Berbasis Kompetensi. Yogyakarta: BPFE.

Pennycuff, S. M. and L. (2008). The Power of Story: Using Storytelling to Improve Literacy Learning. Journal of CrossDisciplinary Perspectives in Education, 1(3), 36-43.

Permatasari, A. I., Sudarmiatin., \& Mudiono, A. (2019). Proses Pembelajaran PKn Berbasis Lesson Study menggunakan Media Boneka Tangan pada Siswa Kelas V. Jurnal Pendidikan: Teori, Penelitian, dan Pengembangan, 4(1), 85-90-90.

Prananta, Y. R., Setyosari, P., \& Santoso, A. (2017). Pengembangan Media Boneka Tangan Berbasis Digital Storytelling. Jurnal Pendidikan: Teori, Penelitian, dan Pengembangan, 2(5), 627-636.

Rosdawita. (2013). Pembelajaran Menyimak Berbasis Pendekatan Kontekstual. Pembelajaran Menyimak Berbasis Pendekatan Kontekstual, 3(2), 2089-3973.

Saddhono. (2012). Meningkatkan Keterampilan Berbahasa Indonesia (Teori dan Aplikasi). Bandung: Karya Putra Darwati.

Sadiman, S. Arief. R. Rahardjo. Haryono, A. R. (2010). Media Pendidikan. Pengertian, Pengembangan, dan Pemanfaatannya. Jakarta: Pustekkom Dikbud dan PT RajaGrafindo Persada.

Syafrina, D., Dermawan, T., \& Widiati, N. (2017). Implementasi Pembelajaran Menyimak di Sekolah Menengah Pertama. Jurnal Pendidikan: Teori, Penelitian, dan Pengembangan, 2(2), 706-713.

Septiadi, I.G.A, Ni Wayan Arini, K. P. (2014). Pengaruh Strategi The Direct Listening Thinking Activity Berbantuan Media Audio terhadap Keterampilan Menyimak Siswa Kelas VI SD. E-Journal Mimbar PGSD Universitas Pendidikan Ganesha Jurusan PGSD, Vol: 2 No:

Septiyani, S., \& Kurniah, N. (20017). Pengaruh Media Big Book terhadap Kemampuan Berbicara pada Anak Usia Dini. Jurnal Ilmiah Potensia, 2(1), 47-56.

Sri Ustari, K. (2018). Pengaruh Model Pembelajaran Dramatic Learning Berbantuan Boneka Tangan terhadap Keterampilan Berbicara. Journal of Education Technology, 2(4)(3), 153-159.

Safitri, A. R., \& Sukidi, M. (2015). Pengaruh Penggunaan Media Boneka Tangan terhadap Keterampilan Bercerita Siswa Kelas II SDN Keret Krembung Sidoarjo. Jurnal Penelitian Pendidikan Guru Sekolah Dasar, 03(2), 1703-1712.

Susan, S. R. (2016). Exploring Aging Attitudes through a Puppet Making Research Study. International Journal of Education and the Arts, $17,13$.

Tarigan, H. (2008). Membaca sebagai Suatu Keterampilan Berbahasa. Bandung: Angkasa.

Whiteland, S. R. (2016). Exploring Aging Attitudes Through a Puppet Making Research Study. International Journal of Education \& the Arts, 17(3), 1-30. 